\title{
Marchiafava-Bignami disease-like lesions due to central nervous system lupus
}

\author{
Yoichiro Kashiwagi, ${ }^{1,2}$ Takahiko Horiuchi, ${ }^{2}$ Chie Harashima, ${ }^{1}$ Fujio Matsubara, ${ }^{3}$ Shin-ichi Harashima ${ }^{2,4}$ \\ ${ }^{1}$ Kashiwagi Clinic, Kitakyushu, Japan \\ ${ }^{2}$ Department of Medicine and Biosystemic Science, Kyushu University, Fukuoka, Japan \\ ${ }^{3}$ Department of Internal Medicine, Shinkokura Hospital, Kitakyushu, Japan \\ ${ }^{4}$ Department of Diabetes and Clinical Nutrition, Kyoto University, Kyoto, Japan
}

Correspondence to Shin-ichi Harashima, harasima@metab.kuhp.kyoto-u.ac.jp

\section{DESCRIPTION}

A 24-year-old woman was hospitalised because of haemolytic anaemia, proteinuria and positive antinuclear and anti-ds-DNA antibodies. Six days after admission, she suddenly showed disturbance of consciousness determined to be mild confusion together with difficulty speaking, inappropriate vocalisations and impaired attention. No abnormal findings were found in cerebral spinal fluid. MRI showed the entire corpus callosum to be swollen, with markedly hyperintense signals on T2-weighted imaging (figure 1A), fluid-attenuated inversion recovery imaging (figure 1B) and diffusion-weighted MRI (DWI) (figure 1C) and an extremely low apparent diffusion coefficient (ADC) value (figure 1D) such as typically found in Marchiafava-Bignami disease (MBD). MBD is an alcohol-associated disorder characterised by demyelination and necrosis of the corpus callosum. ${ }^{1}$ Differential diagnoses are acute stroke, viral meningitis, epidermal mass or diffuse axonal injury and demyelination caused by cytotoxic oedema. ${ }^{2}$ The patient was not alcoholic and was diagnosed as having
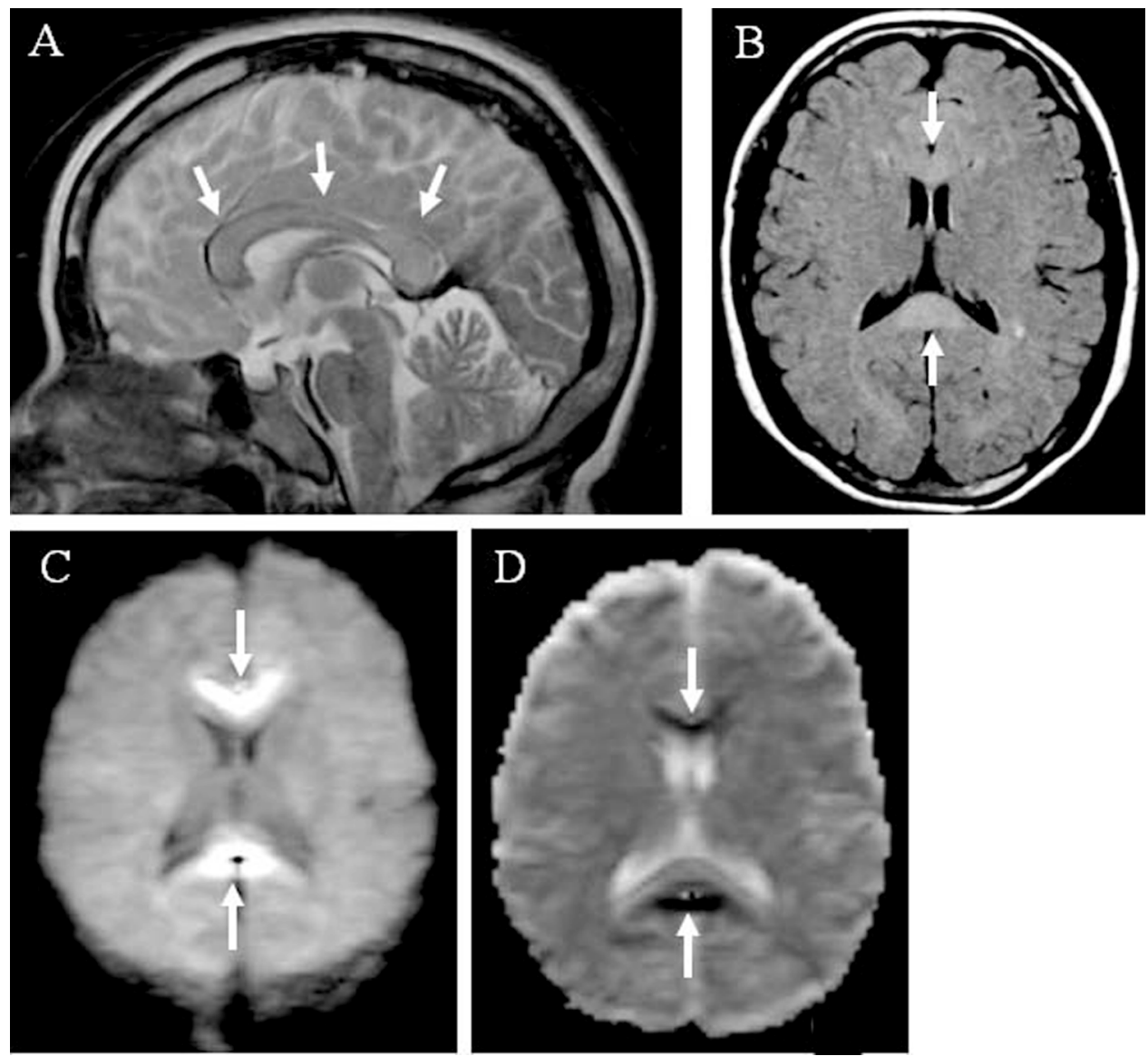

Figure 1 MRI findings at the onset of central nervous system lupus. Sagittal T2-weighted MRI (A), axial fluid-attenuated inversion recovery image (B) and axial diffusion-weighted MRI (C) show hyperintense signal in the entire corpus callosum (white arrows). Axial apparent diffusion coefficient image (D) shows severe diffusion restriction in the entire corpus callosum (white arrows). 


\section{BMJ Case Reports}
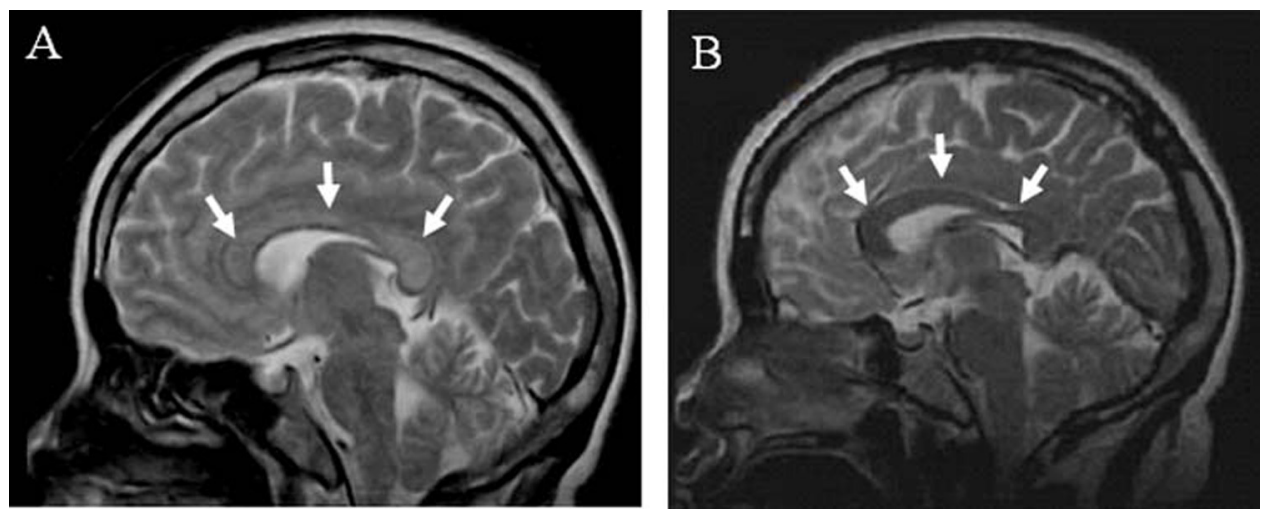

Figure 2 MRI findings in the clinical course. Sagittal T2-weighted MRI shows slightly hyperintense signal in the corpus callosum (white arrows) at 1 month after prednisolone treatment (A), and normal signal intensity in the corpus callosum (white arrows) at 11 months (B).

central nervous system (CNS) lupus. Methylprednisolone pulse (500 mg/day, 3 days) followed by oral prednisolone was effective. She did not show any neurological deficits. Follow-up MRI showed a slightly swollen corpus callosum with mild hyperintense signals at 1 month (figure $2 \mathrm{~A}$ ) and normal findings at 11 months (figure $2 \mathrm{~B}$ ) on T2-weighted images after steroid treatment.

Iguchi et al reported a case of systemic lupus erythematosus with disturbance of consciousness that showed transient signal hyperintensity on DWI and a high ADC value in the cerebral cortex. ${ }^{3}$ Here we present the first case of CNS lupus with MRI images that are compatible with MBD. CNS lupus should be considered in a patient with encepha- lopathy when MRI shows abnormal intensity of callosum signalling.

Competing interests None.

Patient consent Obtained

\section{REFERENCES}

1. Heinrich A, Runge U, Khaw AV. Clinicoradiologic subtypes of Marchiafava-Bignami disease. J Neurol 2004;251:1050-9.

2. Schaefer PW, Grant PE, Gonzalez RG. Diffusion-weighted MR imaging of the brain. Radiology 2000;217:331-45.

3. Iguchi Y, Kimura K, Inoue T, et al. Diffusion-weighted magnetic resonance images in a patient with neuropsychiatric lupus. J Clin Neurosci 2007:14:273-5.

This pdf has been created automatically from the final edited text and images.

Copyright 2010 BMJ Publishing Group. All rights reserved. For permission to reuse any of this content visit http://group.bmj.com/group/rights-licensing/permissions.

BMJ Case Report Fellows may re-use this article for personal use and teaching without any further permission.

Please cite this article as follows (you will need to access the article online to obtain the date of publication).

Kashiwagi Y, Horiuchi T, Harashima C, Matsubara F, Harashima S-I. Marchiafava-Bignami disease-like lesions due to central nervous system lupus. BMJ Case Reports 2010;10.1136/bcr.08.2010.3269, date of publication

Become a Fellow of BMJ Case Reports today and you can:

- Submit as many cases as you like

- Enjoy fast sympathetic peer review and rapid publication of accepted articles

Access all the published articles

- Re-use any of the published material for personal use and teaching without further permission

For information on Institutional Fellowships contact consortiasales@bmjgroup.com

Visit casereports.bmi.com for more articles like this and to become a Fellow 